\title{
Selection, Fitness, and Control of Grape Isolates of Botrytis cinerea Variably Sensitive to Fenhexamid
}

Seiya Saito, United States Department of Agriculture-Agricultural Research Service (USDA-ARS), Commodity Protection and Quality Research Unit, San Joaquin Valley Agricultural Sciences Center, Parlier, CA 93648; and Lance Cadle-Davidson, USDA-ARS, Grape Genetics Research Unit, and Wayne F. Wilcox, Department of Plant Pathology and Plant-Microbe Biology, New York State Agricultural Experiment Station, Cornell University, Geneva, NY 14456

\begin{abstract}
Saito, S., Cadle-Davidson, L., and Wilcox, W. F. 2014. Selection, fitness, and control of grape isolates of Botrytis cinerea variably sensitive to fenhexamid. Plant Dis. 98:233-240.

Of 683 Botrytis cinerea isolates collected from a fungicide-trial vineyard, 31 were classified as putatively resistant to fenhexamid $(50 \%$ effective concentration $\left[\mathrm{EC}_{50}\right] \geq 0.1 \mu \mathrm{g} / \mathrm{ml}$ ). For the resistant isolates that survived and sporulated in culture, colony expansion and conidial germination frequency was significantly reduced relative to the mean of 30 representative baseline isolates $\left(\mathrm{EC}_{50}=0.03 \mu \mathrm{g} / \mathrm{ml}\right)$. Grape berries were inoculated with four isolates representing a range of fenhexamid sensitivities and treated preventively or curatively with fenhexamid concentrations ( 150 to $600 \mathrm{mg} / \mathrm{liter}$ ) representing 25 to $100 \%$ of the recommended rate. All treatments significantly delayed

and $0.15 \mu \mathrm{g} / \mathrm{ml}$ but provided little to no control of isolates with $\mathrm{EC}_{50}$ values of 0.32 and $62.5 \mu \mathrm{g} / \mathrm{ml}$. The latter isolate exhibited a previously unreported F427V mutation of ERG27, an enzyme of ergosterol biosynthesis. In a duplex quantitative polymerase chain reaction test, the ratio of pathogen/host DNA increased significantly for 14 days after inoculation of untreated berries with a baseline isolate but declined slightly in berries treated with fenhexamid at $600 \mathrm{mg} /$ liter 1 day post inoculation. In the vineyard, disease control was affected by the number and rate of fenhexamid applications but $B$. cinerea isolates with $\mathrm{EC}_{50} \geq 0.1 \mu \mathrm{g} / \mathrm{ml}$ were not preferentially selected.
\end{abstract} disease onset and progress caused by isolates with $\mathrm{EC}_{50}$ values of 0.03
Gray mold, caused by the fungus Botrytis cinerea Pers. (anamorph of Botryotinia fuckeliana (de Bary) Whetzel), is a major disease of grape (Vitis spp.) (6). Although various cultural practices play important roles in commercial management programs, control is significantly dependent on the application of fungicides in vineyards where the disease is problematic. Fenhexamid, a hydroxanilide derivative, is a relatively new fungicide. It inhibits $\operatorname{erg} 27$, a 3ketoreductase in the C4-demethylation enzyme complex involved in ergosterol biosynthesis in fungi $(4,20)$. Due to its unique mode of action and good efficacy, fenhexamid is used internationally to manage gray mold $(2,4)$. Although naturally occurring isolates of Botrytis cinerea exhibiting reduced sensitivity to fenhexamid have been detected in many countries $(2,4,9,13,18,19,25,28,29)$, major control failures resulting from resistance to this fungicide have not been reported. One potential reason for the apparent rarity, if not absence, of such cases of "practical resistance" might be reduced fitness of the resistant isolates $(12,27)$.

The fitness costs of fenhexamid resistance have been studied in mutant isolates of $B$. cinerea obtained by UV irradiation (5), chemical mutagenesis $(22,30)$, and site-directed mutagenesis of the erg27 gene (3). These studies showed that, relative to fenhexamidsensitive isolates, resistant mutants were penalized in terms of various physiological characteristics, including mycelial growth, conidial germination, and sclerotial production $(3,5,22,25,30)$. However, little is known about the relative fitness of naturally occurring resistant isolates.

Among several in vitro studies delineating fenhexamid-resistant versus -sensitive B. cinerea isolates on the basis of individual $50 \%$ effective concentration $\left(\mathrm{EC}_{50}\right)$ values, no standard threshold has been applied to either mycelial growth or germ tube elongation.

Corresponding author: S. Saito, E-mail: saitoseiya@ hotmail.com

Accepted for publication 22 August 2013.

http://dx.doi.org/10.1094/PDIS-07-13-0746-RE

(C) 2014 The American Phytopathological Society
For example, whereas some authors defined the discriminatory concentration $\mathrm{EC}_{50}$ value conferring resistance as $0.1 \mathrm{mg} / \mathrm{liter}$ for mycelial growth $(2,7,19)$, others defined it as $0.13 \mathrm{mg} /$ liter (16), $0.2 \mathrm{mg} / \mathrm{liter}(8,25)$, or $50 \mathrm{mg} / \mathrm{liter}(15)$. For germ tube elongation, values of $0.5 \mathrm{mg} /$ liter (8) and $3.0 \mathrm{mg} /$ liter (15) have been proposed. Not only have these various authors defined fenhexamid resistance differently based upon responses to the fungicide in vitro but there also are no data relating these various $\mathrm{EC}_{50}$ values to differences in the control of disease caused by such isolates in vivo.

In this study, we (i) investigated the relative fitness of naturally occurring $B$. cinerea isolates putatively resistant to fenhexamid, (ii) related the range of $\mathrm{EC}_{50}$ values determined for various $B$. cinerea isolates to the suppression of disease caused by them following treatment with fenhexamid in preventive and curative manners, and (iii) monitored the efficacy of fenhexamid and the potential selection of fenhexamid-resistant isolates under different use patterns in the field. Secondary objectives were to determine a possible point mutation within the erg27 gene of a highly resistant phenotype detected during the course of the study, and to utilize a newly developed quantitative polymerase chain reaction (qPCR) technique to monitor the development of $B$. cinerea within berries following curative treatment with fenhexamid.

\section{Materials and Methods}

Plant and fungal materials. All B. cinerea isolates were collected from a vineyard of the Vitis interspecific hybrid 'Vignoles' at the New York State Agricultural Experiment Station in Geneva, NY, which has been used for Botrytis fungicide efficacy trials annually since 2002 . All vines were 15 to 16 years old, and pruned and trained to the Umbrella-Kniffin system.

In April 2010, B. cinerea isolates were collected at arbitrary locations throughout the vineyard from dead grapevine rachises that had overwintered on the vines. In the laboratory, each rachis was surface sterilized for $1 \mathrm{~min}$ in $0.5 \%$ sodium hypochlorite, rinsed in sterile distilled water (SDW), and air dried. Rachises were transferred onto a sterile steel mesh screen over sterile paper towels in a covered transparent plastic container and incubated at $-12^{\circ} \mathrm{C}$ overnight. The container was then transferred to lighted 
shelving and the paper towels were saturated with SDW to establish high relative humidity. After 2 weeks of incubation at $25^{\circ} \mathrm{C}$ under a photoperiod of $12 \mathrm{~h}$ of light and $12 \mathrm{~h}$ of darkness, a $B$. cinerea colony was transferred from each sporulating rachis onto potato dextrose agar (PDA) using single-spore isolation. The resulting isolates were maintained on PDA at room temperature.

In September 2010 and 2011, additional B. cinerea isolates were collected from diseased grape berries in each experimental plot subjected to the various fenhexamid spray programs described below. Sporulating berries were harvested individually into plastic bags, transferred to PDA plates in the laboratory, and incubated at room temperature for 3 to 5 days. Actively growing mycelia transferred to new PDA plates and developing colonies were subcultured at least twice. Single-spore isolates of each culture were then made and maintained as described above.

Fungicide sensitivity tests. A commercial formulation of fenhexamid (Elevate 50WDG; Arysta LifeScience North America) was used for all experiments. Sensitivity to fenhexamid was assessed as described previously (22). Briefly, for each B. cinerea isolate, 4-mm-diameter plugs from the leading edge of 3- to 4-dayold colonies growing on PDA were excised with a sterile cork borer and transferred singly to new 9-cm-diameter petri dishes containing PDA amended with one of at least six concentrations of fenhexamid within the range of 0.0195 to $80.0 \mathrm{mg} / \mathrm{liter}$ (depending upon the isolate), at twofold dilutions. After incubation for 3 days at $23^{\circ} \mathrm{C}$ in the dark, the resulting colony diameters were measured and means were calculated after subtracting the diameter of the original plug. Tests for each isolate were replicated three times, utilizing one plate per fungicide concentration. $\mathrm{EC}_{50}$ values were determined for each isolate using regression equations from the resulting log-linear dose-response curves $(8,14)$. Because an $\mathrm{EC}_{50}$ value $>0.1 \mathrm{mg} /$ liter has been used most frequently in previous studies to denote a fenhexamid-resistant phenotype $(2,7,19)$, we also used this value to select putatively resistant isolates for additional testing.

Fitness parameters. Putatively resistant isolates identified above were compared against isolates with $\mathrm{EC}_{50}$ values $<0.1$ $\mathrm{mg} / \mathrm{liter}$ in terms of mycelial growth and conidial germination. Three 4-mm-diameter mycelial plugs per isolate were transferred individually to the centers of replicate 9-cm-diameter PDA plates. After $60 \mathrm{~h}$ of incubation at $23^{\circ} \mathrm{C}$ in the dark, the mean colony diameter was estimated based on six measurements of each colony to account for imperfect circular growth. For conidial germination tests, 2-week-old cultures of each isolate grown on PDA were used to prepare suspensions containing $1 \times 10^{4}$ to $1 \times 10^{5}$ conidia ml $^{-1}$. A $50-\mu$ l subsample of each conidial suspension was spread on a
PDA plate, and their germination frequency was determined after 6 $\mathrm{h}$ of incubation at $23^{\circ} \mathrm{C}$ in the dark by examining $>200$ conidia on each of three replicate plates per treatment at $\times 20$ magnification. The data of colony diameter and conidial germination frequency were subjected to an analysis of variance, followed by Dunnett's multiple range test using Ekuseru-Toukei software 2010 (Social Survey Research Information Co., Ltd.).

Field programs. Control programs utilizing various rates of fenhexamid ranging from $140 \mathrm{~g} / \mathrm{ha}$ to the labeled rate of $560 \mathrm{~g} / \mathrm{ha}$ and different spray timings were applied over two consecutive seasons in the vineyard described above (Table 1). Individual plots, consisting of four consecutive vines spaced $1.8 \mathrm{~m}$ apart in a single row, were arranged in a randomized complete block design with six replications, and different vines were utilized in each year of the experiment. Treatments were applied with a hooded-boom sprayer operating at a pressure of $2,069 \mathrm{kPa}$ and delivering a volume of 467 liters/ha at late bloom and 935 liters/ha subsequently. In addition to the variable treatment regimes, all plots were sprayed four and three times during the 2010 and 2011 growing seasons, respectively, with one or more of the following to control other fungal diseases and insect pests: acetamiprid, carbaryl, fenarimol, fenpropathin, mancozeb, quinoxyfen, or sulfur. None of these materials are in the same Fungicide Resistance Action Committee resistance group as fenhexamid, nor do they have significant activity against $B$. cinerea.

At harvest, 10 sporulating berries were arbitrarily selected from throughout each plot, and single-spore isolates of $B$. cinerea were obtained and assayed for sensitivity to fenhexamid, as described above. At this time, disease severity in each plot also was rated using the Horsfall-Barratt scale by examining 25 clusters selected arbitrarily from the center two vines of each plot. These data were converted to represent a percentage of the cluster surface area exhibiting symptoms or signs of gray mold using the midpoint of the disease severity range (17); then, the converted data were subjected to an analysis of variance to test the effect of the various treatments tested using JMP software (SAS Institute).

Inoculation tests on grape berries. Four $B$. cinerea isolates that represented the range of fenhexamid sensitivities encounteredw001 ( $\left.\mathrm{EC}_{50}=0.033 \mathrm{mg} / \mathrm{liter}\right), 13-54\left(\mathrm{EC}_{50}=0.148 \mathrm{mg} / \mathrm{liter}\right)$, w011 $\left(\mathrm{EC}_{50}=0.318 \mathrm{mg} / \mathrm{liter}\right)$, and $15-80\left(\mathrm{EC}_{50}=62.5 \mathrm{mg} / \mathrm{liter}\right)$-were used in inoculation tests to determine their relative sensitivities to control by fenhexamid when challenged in both a preventive and curative manner. Table grape berries ('Flame Seedless') purchased at a local supermarket were used in all tests, which were conducted in a sterile hood unless otherwise indicated. Unblemished berries were cut from the rachis with sterile pruning shears before testing.

Table 1. Effect of fenhexamid application timing and rate on gray mold control and selection for resistant Botrytis cinerea isolates

\begin{tabular}{|c|c|c|c|c|c|c|}
\hline \multirow[b]{2}{*}{ Treatment } & \multicolumn{4}{|c|}{ Application and rate ${ }^{x}$} & \multirow[b]{2}{*}{ Disease severity $(\%)^{\mathrm{y}}$} & \multirow[b]{2}{*}{ Resistant isolates/total isolates ${ }^{\mathrm{z}}$} \\
\hline & 1 & 2 & 3 & 4 & & \\
\hline \multicolumn{7}{|l|}{2010} \\
\hline Control & - & - & - & - & $7.0 \mathrm{a}$ & $0 / 45$ \\
\hline 1 & ++ & ++ & ++ & ++ & $2.0 \mathrm{~b}$ & $2 / 50$ \\
\hline 2 & +++ & +++ & +++ & +++ & $0.1 \mathrm{~b}$ & $2 / 43$ \\
\hline 3 & +++ & - & +++ & - & $0.6 \mathrm{~b}$ & $0 / 38$ \\
\hline 4 & +++ & +++ & - & _- & $1.8 \mathrm{~b}$ & $6 / 40$ \\
\hline 5 & +++ & +++ & +++ & - & $0.7 \mathrm{~b}$ & $4 / 34$ \\
\hline 6 & - & - & +++ & +++ & $0.9 \mathrm{~b}$ & $4 / 47$ \\
\hline \multicolumn{7}{|l|}{2011} \\
\hline Control & - & - & - & - & $25.8 \mathrm{a}$ & $3 / 55$ \\
\hline 1 & + & + & + & + & $12.7 \mathrm{ab}$ & $3 / 49$ \\
\hline 2 & ++ & ++ & ++ & ++ & $9.6 \mathrm{~b}$ & $2 / 58$ \\
\hline 3 & +++ & +++ & +++ & +++ & $2.6 \mathrm{~b}$ & $2 / 46$ \\
\hline
\end{tabular}

${ }^{\mathrm{x}}$ Approximate phenological stages for designated spray application: $1=$ late bloom, $2=$ bunch closure, $3=$ véraison, $4=$ véraison +2 weeks; 2010 dates $=$ 17 June, 20 July, 10 and 24 August, respectively; 2011 dates = 26 June, 24 July, 16 and 29 August, respectively; - = no application, + = fenhexamid at 140 $\mathrm{g} / \mathrm{ha},++=$ fenhexamid at $280 \mathrm{~g} / \mathrm{ha}$, and $+++=$ fenhexamid at $560 \mathrm{~g} / \mathrm{ha}$.

${ }^{y}$ Disease severity was estimated using the Horsfall-Barratt scale $(0$ to 11$)$ for 25 clusters from each of six replicate plots per treatment. Least squares means were subjected to the Tukey-Kramer honestly significant difference test. Means within a single year not followed by a common letter are significantly different at $P<0.05$.

${ }^{\mathrm{z}}$ Isolates were classified as resistant based on $50 \%$ effective concentration $\left(\mathrm{EC}_{50}\right)$ value $\geq 0.1 \mathrm{mg} / \mathrm{liter}$. 
For the preventive assays, inoculum of the desired $B$. cinerea isolates was prepared by transferring mycelium from the surface of a 1-week-old colony growing on PDA to the cut surface of untreated berries. The berries were cut lengthwise with a sterile blade and incubated in a covered petri dish at room temperature and a 12-h photoperiod. After 5 to 6 days, each berry was transferred to a clean petri dish with its cut surface placed against an intact berry previously treated with fenhexamid. The fenhexamid concentrations corresponded to 25,50 , and $100 \%$ of the recommended perhectare rate of 936 liters/ha. The berries were dipped in the appropriate concentration for about $1 \mathrm{~min}$, placed on a sterile steel mesh screen, and air dried for $1 \mathrm{~h}$.

In one assay (Preventive-1), treated berries were placed in contact with the inoculated berries immediately after drying, the lidless petri dishes containing them were transferred to a transparent plastic container along with SDW-saturated paper towels, and the container was covered to maintain high humidity. In a second assay (Preventive-5), fenhexamid-treated berries were prepared as above but were stored at $8^{\circ} \mathrm{C}$ for 5 days after drying before they were inoculated. For both assays, inoculated berries were incubated in the sealed chambers for 7 days at $25^{\circ} \mathrm{C}$ under a regime of $12 \mathrm{~h}$ of light and $12 \mathrm{~h}$ of darkness. In both assays, berries were examined every $24 \mathrm{~h}$ and the number deemed infected (based on a cracking of the epidermis and exudation near the point of contact with the inoculum source) was recorded.

At least 15 berries were used for each fenhexamid concentration-isolate combination, and each experiment was performed twice, with all isolates included in every run of an experiment. The data were pooled to create a Kaplan-Meier survival curve based upon the frequency of symptomatic berries at each observation time. The Kaplan-Meier survival curve is considered superior to conventional statistical techniques for analyzing time-to-event data for discrete occurrences such as spore germination, propagule death, or disease onset because it can accommodate censored observations (i.e., cases where the event has not occurred by the end of study; 9,23). Log-rank tests were performed in order to compare the results between the control and each treatment using the Ekuseru-Toukei 2010 software (Social Survey Research Information Co., Ltd.).

For the curative tests, suspensions containing $B$. cinerea at $1.0 \times$ $10^{5}$ conidia/ml were prepared from 7- to 10 -day-old cultures growing on PDA; then, $1 \mu \mathrm{l}$ of conidial suspension was inoculated onto each of five wounds per berry, made by inserting a $3-\mathrm{mm}$ sterile needle into the cheek of the surface-sterilized fruit. The noninoculated berry face was taped onto the bottom of open petri dishes wounded side up, and the berries were incubated in a sealed plastic container as described above. Either 24 or $72 \mathrm{~h}$ after inoculation (Curative-1 or Curative-3, respectively), approximately $3 \mathrm{ml}$ of a fungicide solution containing fenhexamid at $0.15,0.3$, or $0.6 \mathrm{~g} / \mathrm{liter}$ was sprayed onto the berries in each petri dish, using a portable paint sprayer (Precision Valve Corporation), and the containers were resealed. The control treatment consisted of SDW sprayed under the same conditions. Disease development was rated daily from 4 until 7 days post inoculation (dpi) according to the following scale: $0=$ no symptoms, $1=<12.5 \%$ of berry surface necrotic, $2=12.5$ to $25 \%$ necrotic, $3=25$ to $50 \%$ necrotic, $4=50$ to $75 \%$ necrotic, and $5=75$ to $100 \%$ necrotic. Both the Curative- 1 and -3 assays were performed three times, using 20 berries per fenhexamid concentration for each assay, with all four $B$. cinerea isolates included in each run of the experiment.

To analyze the data, the disease rating scale value for each treatment was transformed into midpoints of $0,6.25,18.75,37.5,62.5$, and 87.5 , for the value 0 to 5 , respectively. The effectiveness was analyzed using the area under the disease progress curve (AUDPC). The AUDPC was calculated based on the sum of midpoints of the 20 berries from days 4 to 7 , according to the formula described by Madden et al. (17). The means of three AUDPC values for each fungicide concentration-isolate combination were subjected to analysis of variance, followed by Tukey's test for means separation, using SAS 9.3 (SAS Institute).
Duplex qPCR. To monitor the dynamic effect of fenhexamid on host colonization by $B$. cinerea when applied in a curative manner, a recently developed duplex qPCR technique (21) was employed to quantify changes in pathogen DNA within inoculated berries following treatment. Conidia of fenhexamid-sensitive $B$. cinerea isolate w001 were inoculated onto wounded berries, which were sprayed $24 \mathrm{~h}$ later with a solution containing fenhexamid at 0.6 $\mathrm{g} /$ liter (or SDW for the control treatment), as described above for the Curative- 1 assay. The petri dishes containing inoculated berries were incubated for 15 days at $25^{\circ} \mathrm{C}$ under an illumination regime of $12 \mathrm{~h}$ of light and $12 \mathrm{~h}$ of darkness, as described above. Three berries were sampled from both the control and fenhexamid treatment immediately after inoculation and 3, 10, and 14 days later. After sampling, individual berries of 5.8 to $6.0 \mathrm{~g}$ each were placed in a plastic bag, flash frozen with liquid nitrogen, and stored at $-80^{\circ} \mathrm{C}$ until further use. DNA extraction from the berries was performed using the cetyltrimethylammonium bromide method described previously (21). For the detection of $B$. cinerea and grape DNA, the $\mathrm{Bc} 3$ primer and probe set (24) and resveratrol synthase gene I primer and probe set (26) were used, respectively. Duplex qPCR for the detection of grape and $B$. cinerea DNA and the reaction mixtures and conditions were as described previously (21). A pathogen coefficient (PC) was calculated using the threshold cycle number for the grape gene (amplified from a constant amount of total DNA) divided by that for B. cinerea DNA, which is likely to vary among treatments (21).

\section{Results}

Sensitivity to fenhexamid and fitness parameters. Of the 683 isolates collected from the trial vineyard (183 prior to the start of vine growth in April 2010 and 290 and 210 at grape maturity in September 2010 and 2011, respectively), 31 were classified as putatively resistant to fenhexamid based on $\mathrm{EC}_{50}$ values $>0.1$ $\mathrm{mg} / \mathrm{liter}$. Of these, 19 were selected for further study, because the others grew poorly when subcultured onto PDA. Of the 19, 3 additional isolates eventually stopped growing after the repeated subculturing necessary for their maintenance and testing, and 3 others lost most or all of their ability to sporulate in culture; the results from such isolates were excluded from subsequent data analyses. Approximately $5 \%$ of the sensitive isolates also grew poorly after repeated subculturing and could not be studied further. Thirty isolates with $\mathrm{EC}_{50}$ values $<0.1 \mathrm{mg} /$ liter collected in April 2010 were randomly selected to represent the baseline population in these tests. Based on the mean $\mathrm{EC}_{50}$ value of $0.034 \mathrm{mg} /$ liter for the baseline group, resistance factors for the 19 resistant isolates were 3.4 to 1838.2 (Table 2).

Mean mycelial growth for the resistant isolates was $56.6 \%$ of the mean for the 30 baseline isolates, with a range of 1.8 to $105 \%$ (relative to the baseline) for individual isolates; among the most sensitive 9 of these isolates (i.e., those with $\mathrm{EC}_{50}$ values between 0.1 and $0.2 \mathrm{mg} / \mathrm{liter}$ ), the mean and range was $47.5 \%$ and 5.4 to $96.4 \%$ relative to the baseline, respectively. Relative to the baseline group, differences in mean mycelial growth were significant at $P<$ 0.001 for 10 of the 16 individual resistant isolates and at $P=0.05$ for 1 other (Table 2). The mean frequency of conidial germination for the 15 resistant isolates was $88.6 \%$ (34 to $104 \%$ ) relative to the baseline isolates. The frequency of six of these resistant isolates was significantly lower $(P=0.01)$ than the mean for the baseline isolates (Table 2).

As a result of the extremely high level of resistance observed for isolate $15-80\left(\mathrm{EC}_{50}=62.5 \mathrm{mg} / \mathrm{liter}\right)$, we subjected it to additional genetic analysis, following a previously reported method (20). Sequencing of the erg27 gene revealed that the coding for phenylalanine (TTC) was substituted with that for valine (GTC) at position 427.

Fenhexamid spray program. The weather was not favorable for B. cinerea in 2010 and few bunch rot symptoms were observed, even in the control plots. Although there were no significant differences among them, all six fenhexamid programs reduced disease severity significantly $(P<0.05)$ relative to the unsprayed control 
(Table 1). Of the B. cinerea isolates collected from each plot at maturity, 4 to $15 \%$ of those collected from five of the six sprayed treatments had $\mathrm{EC}_{50}>0.1$ and, thus, were classified as resistant; no such isolates were collected from the unsprayed check plots or those treated with the highest fenhexamid rate at late bloom and verraison (Table 1). In 2011, the weather was much more favorable for $B$. cinerea proliferation, as was evident by the increased disease level in the check treatment. When applied full season, the magnitude of disease control was rate dependent; that is, 90, 63, and $51 \%$, with the differences relative to the untreated check significant $(P<0.05)$ for the two highest rates but not the lowest, respectively (Table 1). However, this rate effect did not appear to result from variable control of $B$. cinerea isolates resistant to fenhexamid, because such phenotypes were recovered from 3 to $6 \%$ of the sampled berries in all three of the fungicide treatments as well as the unsprayed check (Table 1).

The distribution of fenhexamid sensitivities among $B$. cinerea isolates collected from these experimental plots in 2010 and 2011 is shown in Figure 1. The vast majority ( 94 and $95 \%$, respectively) had $\mathrm{EC}_{50}$ values $<0.1 \mathrm{mg} /$ liter and, therefore, were classified as sensitive. There was no difference in the distribution of sensitivity to fenhexamid between the 2 years, according to Friedman's test ( $P$ $=0.763$ ), suggesting that there was no shift toward decreased sensitivity to fenhexamid as a result of these spray programs following the high-pressure 2011 season.

Control of resistant isolates by fenhexamid. In the Preventive-1 test, treatment with any fenhexamid concentration significantly reduced infection of berries by the sensitive $B$. cinerea isolate w001 $\left(\mathrm{EC}_{50}=0.033 \mathrm{mg} / \mathrm{liter}\right)$ as compared with the control $(P=$ $0.016, P<0.0001$, and $P<0.0001$ for treatment with $0.15,0.3$, and $0.6 \mathrm{mg} /$ liter, respectively). For example, nearly $60 \%$ of the untreated berries were symptomatic within $2 \mathrm{dpi}$ and almost all were symptomatic within 3 days, whereas approximately half of the berries treated with 0.3 or $0.6 \mathrm{mg} /$ liter remained symptomless 4 and $6 \mathrm{dpi}$, respectively (Fig. 2). Similarly, for the putatively resistant isolate 13-54 $\left(\mathrm{EC}_{50}=0.148 \mathrm{mg} / \mathrm{liter}\right)$, symptoms developed significantly more slowly on berries treated with all fenhexamid concentrations relative to those in the check treatment $(P=0.008$,
$P<0.0001$, and $P<0.0001$ for $0.15,0.3$, and $0.6 \mathrm{mg} /$ liter, respectively). In contrast, no fenhexamid treatment significantly affected the progress of infection by the two $B$. cinerea isolates with $\mathrm{EC}_{50}$ values of 0.318 or $62.5 \mathrm{mg} /$ liter $(P=0.44$ to 0.87 , depending on the isolate and concentration used). The same trend was observed in the Preventive-5 treatment, with the various fenhexamid concentrations providing similar levels of control relative to the untreated check against the baseline isolate w001 and isolate 13-54 $(P<$ 0.001 for both isolates at concentrations of 0.3 and $0.6 \mathrm{mg} / \mathrm{liter} ; P$ $=0.296$ and 0.001 at a concentration of $0.15 \mathrm{mg} /$ liter for isolate w001 and 13-54, respectively). In contrast, no tested fenhexamid concentration provided significant control of the two more highly resistant isolates, $(P=0.74$ to 0.98 , depending upon isolate and concentration). When data for untreated berries inoculated with each putatively resistant isolate were compared with those for baseline isolate w001, significant differences were observed for isolate $\mathrm{w} 011\left(\mathrm{EC}_{50}=0.318 \mathrm{mg} / \mathrm{liter}\right)$ in both the Preventive- 1 and

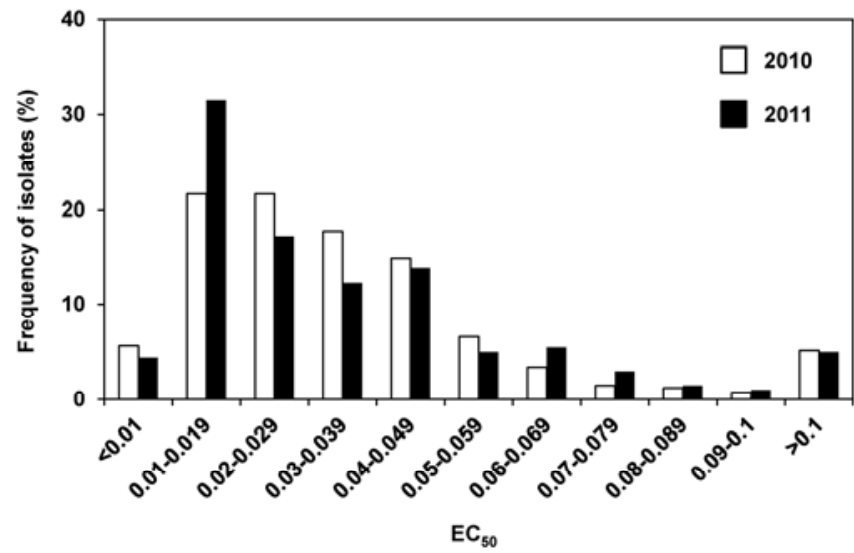

Fig. 1. Frequency distributions of $50 \%$ effective concentration $\left(E C_{50}\right)$ values in response to fenhexamid for 683 Botrytis cinerea isolates collected from a trial vineyard of Vitis interspecific hybrid 'Vignoles' from April 2010 through September 2011.

Table 2. Relationship between 50\% effective concentration $\left(\mathrm{EC}_{50}\right)$ value and (i) mycelial growth or (ii) conidial germination frequency for selected isolates of Botrytis cinerea

\begin{tabular}{|c|c|c|c|c|}
\hline \multirow[b]{2}{*}{ Isolate } & \multirow[b]{2}{*}{$\mathbf{E C}_{50}(\mathrm{mg} / \text { liter })^{\mathrm{v}}$} & \multirow[b]{2}{*}{ Resistance factor ${ }^{w}$} & \multicolumn{2}{|c|}{ Mean $\pm \mathbf{S E}^{\mathbf{u}}$} \\
\hline & & & Mycelial growth $(\mathbf{m m})^{\mathrm{x}}$ & Germination frequency $(\%)^{y}$ \\
\hline Baseline $^{z}$ & 0.034 & 1.0 & $70.4 \pm 0.5$ & $94.3 \pm 3.0$ \\
\hline w001 & 0.033 & 1.0 & $69.5 \pm 0.4$ & $95.2 \pm 0.3$ \\
\hline w084 & 0.116 & 3.4 & $64.4 \pm 0.5$ & n.d. \\
\hline $13-66$ & 0.123 & 3.6 & $23.1 \pm 1.3 * *$ & $88.0 \pm 1.3 * *$ \\
\hline w109 & 0.127 & 3.7 & $61.7 \pm 1.8$ & $32.2 \pm 0.5 * *$ \\
\hline $18-13$ & 0.138 & 4.1 & 0 & $90.2 \pm 0.1$ \\
\hline $21-36$ & 0.146 & 4.3 & $3.8 \pm 0.6 * *$ & n.d. \\
\hline $13-54$ & 0.148 & 4.4 & $34.8 \pm 2.9 * *$ & $96.0 \pm 0.3$ \\
\hline w121 & 0.153 & 4.5 & $43.3 \pm 2.6 * *$ & $95.1 \pm 0.5$ \\
\hline $38-61$ & 0.162 & 4.8 & $39.0 \pm 5.8 * *$ & $97.7 \pm 0.9$ \\
\hline $14-73$ & 0.181 & 5.3 & $22.0 \pm 1.3 * *$ & $88.2 \pm 1.0 * *$ \\
\hline w087 & 0.196 & 5.8 & $8.9 \pm 0.5 * *$ & $84.6 \pm 4.4$ \\
\hline w138 & 0.242 & 7.1 & $10.9 \pm 1.3 * *$ & n.d. \\
\hline w034 & 0.295 & 8.7 & $74.1 \pm 0.8$ & $54.9 \pm 5.2 * *$ \\
\hline w011 & 0.318 & 9.4 & $70.2 \pm 0.9$ & $85.9 \pm 2.6 * *$ \\
\hline w035 & 0.419 & 12.3 & $40.1 \pm 1.2 * *$ & $73.7 \pm 4.6 * *$ \\
\hline $17-38$ & 0.434 & 12.8 & 0 & $95.3 \pm 1.4$ \\
\hline $21-42$ & 0.506 & 14.9 & $68.7 \pm 0.2$ & $96.7 \pm 0.1$ \\
\hline w116 & 1.626 & 47.8 & $1.3 \pm 1.0 * *$ & $80.5 \pm 1.9 * *$ \\
\hline w066 & 1.645 & 48.4 & 0 & n.d. \\
\hline $15-80$ & 62.50 & $1,838.2$ & $62.5 \pm 0.3 *$ & $94.7 \pm 0.7$ \\
\hline
\end{tabular}

"Significantly different mean \pm standard error (SE) relative to the baseline according to Dunnett's multiple comparison test; * and ** indicate $P<0.05$ and

0.01 , respectively; 0 indicates isolates with no mycelial growth during the experiment, which were excluded from Dunnett's test; n.d. = not determined.

${ }^{v}$ Fenhexamid $\mathrm{EC}_{50}$ value for mycelial growth.

${ }^{\mathrm{w}}$ Resistance factor relative to the baseline.

${ }^{x}$ Mean colony diameter after incubation for $60 \mathrm{~h}$ on potato dextrose agar (PDA) $(n=3)$

y Percentage of germinated conidia after incubation on PDA at $23^{\circ} \mathrm{C}$ for $6 \mathrm{~h}(n=600)$.

${ }^{\mathrm{z}}$ Values represent those for a composite population of 30 isolates randomly selected from among 652 with $\mathrm{EC}_{50}$ values $<0.1 \mathrm{mg} / \mathrm{liter}$. 
-5 assays $(P=0.028$ and 0.004 , respectively), indicating that it had a longer incubation period than the other isolates tested.

When applied $1 \mathrm{dpi}$, all fenhexamid concentrations provided substantial control of the baseline isolate w001 and isolate 13-54 relative to the check treatment, delaying both the onset of colonization and limiting its subsequent progress (Table 3). However, as in the protective assays, none of the fenhexamid treatments provided any control of disease caused by isolate w011 or 15-80 when rated $7 \mathrm{dpi}$, although the highest concentration did modestly impede the progress of colonization by isolate w011 during its initial stages (Fig. 3; Table 3). When applied 3 dpi, no treatment had any effect on disease caused by either the most sensitive (w001) or most re-

\section{Preventive-1}
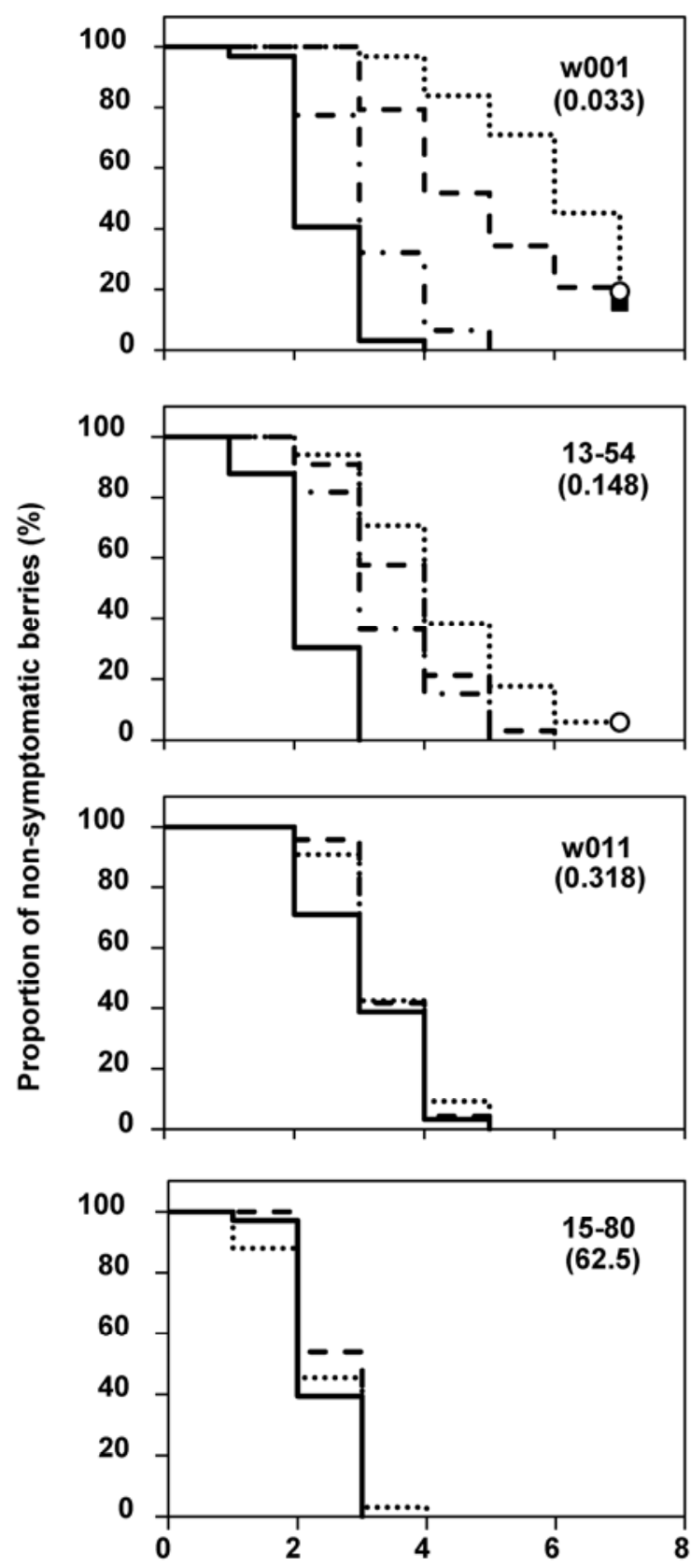

Days post inoculation

\section{Preventive-5}
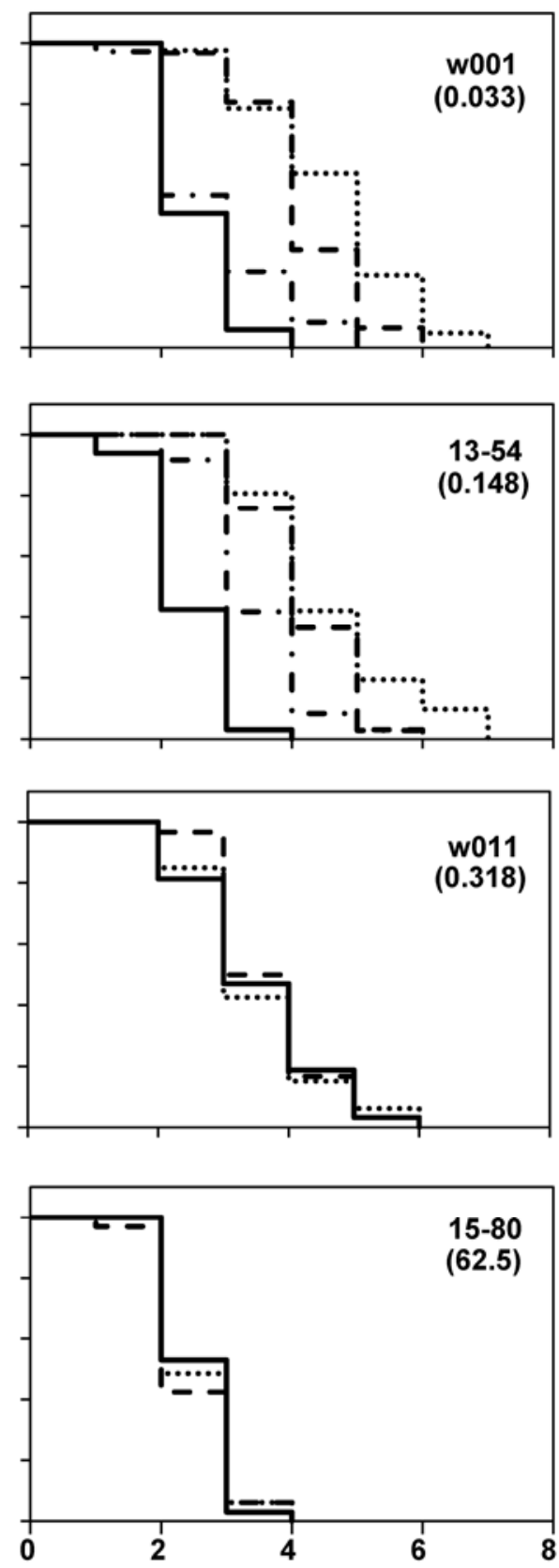

Days post inoculation

control \begin{tabular}{ccc}
$0.15 \mathrm{~g} / \mathrm{L}$ & $0.3 \mathrm{~g} / \mathrm{L}$ & $0.6 \mathrm{~g} / \mathrm{L}$ \\
\hline
\end{tabular}

Fig. 2. Progression of symptom development on grape berries treated preventively with different rates of fenhexamid either 1 or 5 days before inoculation with one of four Botrytis cinerea isolates exhibiting different levels of sensitivity to the fungicide ( $50 \%$ effective concentration $\left[\mathrm{EC}_{50}\right.$ ] values in parentheses). Both the 1 - and 5 - day preventive assays were conducted twice, with at least 15 berries per treatment in all runs of the experiments. All data for each assay were pooled to create Kaplan-Meier survival curves. The lowest fenhexamid concentration ( $0.15 \mathrm{~g} /$ /iter) was not tested against isolates w011 and 15-80. Solid squares and open circles denote final assessment in the Preventive1 trial for 0.3 - and 0.6 -g/liter treatments, respectively. 
sistant (15-80) isolate, although the highest fenhexamid rate did provide moderate control of isolate w011 relative to the check treatment (Table 3; Fig. 3).

B. cinerea colonization quantified by duplex qPCR. Immediately after inoculation ( $0 \mathrm{dpi})$, there was no significant difference $(P=0.80, t$ test) in the PC for berries in the treated and untreated groups (Fig. 4). By 3 dpi, the PC had risen in both (Fig. 4), although that for the berries treated with fenhexamid $24 \mathrm{~h}$ after inoculation was significantly lower than that for the controls $(P=0.03)$, indicating that fenhexamid had inhibited $B$. cinerea growth over the 2 days following treatment (Fig. 4). The PC for check berries continued to increase throughout the 2-week duration of the experiment, whereas it declined modestly in the fenhexamid-sprayed berries over the remaining course of the experiment, resulting in pronounced differences between the two treatments at the 10 and 14 dpi sampling times ( $P=0.001$ and $P<0.0001$, respectively).

\section{Discussion}

Although fenhexamid-resistant isolates were detected at frequencies of 6.2 and $4.9 \%$ in the trial vineyard in 2010 and 2011, respectively, fenhexamid applications managed Botrytis bunch rot effectively in both years, in accordance with previous reports (2,25).

The continued effectiveness of fenhexamid may be partly due to the fitness cost to the pathogen of maintaining resistance. The first indicator of this was that only 13 of $31(42 \%)$ isolates classified as resistant to fenhexamid $\left(\mathrm{EC}_{50}>0.1 \mathrm{mg} / \mathrm{liter}\right)$ survived in culture, versus approximately $95 \%$ of isolates classified as sensitive $\left(\mathrm{EC}_{50}\right.$ $<0.1 \mathrm{mg} /$ liter). Further, in comparing physiological characteristics among $30 \mathrm{~B}$. cinerea isolates classified as sensitive to fenhexamid versus the 13 resistant isolates that maintained viability in culture, all but one of the latter group were significantly reduced in fitness as quantified by mycelial growth or conidial germination frequency. However, our examination of potential fitness costs associated with fenhexamid resistance was not exhaustive, because other potentially relevant parameters subject to testing in vitro (e.g., conidial production, sclerotial production, and sclerotial viability) were not included in the study. In vitro fitness costs have also been observed for fenhexamid-resistant mutants obtained by UV irradiation (5) or chemical mutagenesis $(22,30)$.

Although there was a clear link between fenhexamid resistance and in vitro fitness costs for this pathogen, in vivo fitness costs seem likely more relevant to practical disease management. Billard et al. (3) generated three fenhexamid-resistant mutants by site-directed mutagenesis of the erg27 gene and found that these nega-

Table 3. Mean values of the area under the disease progress curve (AUDPC) in response to different concentrations of fenhexamid applied in a curative manner 1 or 3 days post inoculation

\begin{tabular}{lcccc}
\hline & \multicolumn{4}{c}{ Isolate $\left(\mathbf{E C}_{\mathbf{5 0}}\right)^{\mathbf{z}}$} \\
\cline { 2 - 5 } Fenhexamid & $\begin{array}{c}\mathbf{w 0 0 1} \\
\mathbf{( 0 . 0 3 3})\end{array}$ & $\begin{array}{c}\mathbf{1 3 - 5 4} \\
\mathbf{( 0 . 1 4 8})\end{array}$ & $\begin{array}{c}\mathbf{w 0 1 1} \\
\mathbf{( 0 . 3 1 8})\end{array}$ & $\begin{array}{c}\mathbf{1 5 - 8 0} \\
\mathbf{( 6 2 . 5})\end{array}$ \\
\hline Curative-1 & & & & \\
Control & $3,521.9 \mathrm{a}$ & $4,036.8 \mathrm{a}$ & $3,366.7 \mathrm{a}$ & $4,225.0 \mathrm{a}$ \\
$0.15 \mathrm{~g} /$ liter & $732.2 \mathrm{~b}$ & $660.4 \mathrm{~b}$ & n.d. & n.d. \\
$0.3 \mathrm{~g} /$ liter & $439.6 \mathrm{~b}$ & $425.0 \mathrm{~b}$ & $3,072.9 \mathrm{a}$ & $4,367.0 \mathrm{a}$ \\
$0.6 \mathrm{~g} /$ liter & $217.7 \mathrm{~b}$ & $208.3 \mathrm{~b}$ & $2,606.3 \mathrm{ab}$ & $4,422.9 \mathrm{a}$ \\
Curative-3 & & & & \\
Control & $3,666.7 \mathrm{a}$ & $3,776.3 \mathrm{a}$ & $3,605.2 \mathrm{a}$ & $4,277.1 \mathrm{a}$ \\
$0.15 \mathrm{~g} /$ liter & $3,356.3 \mathrm{a}$ & $3,385.4 \mathrm{a}$ & n.d. & n.d. \\
$0.3 \mathrm{~g} /$ liter & $3,382.3 \mathrm{a}$ & $3,509.0 \mathrm{a}$ & $2,331.3 \mathrm{~b}$ & $4,327.4 \mathrm{a}$ \\
$0.6 \mathrm{~g} /$ liter & $3,351.0 \mathrm{a}$ & $2,638.5 \mathrm{a}$ & $1,561.5 \mathrm{c}$ & $4,235.4 \mathrm{a}$ \\
\hline
\end{tabular}

${ }^{\mathrm{z}}$ Berries were treated with different concentrations of fenhexamid (formulated as Elevate 50WG) either 1 or 3 days after inoculation with one of the four Botrytis cinerea isolates indicated (individual 50\% effective concentration [ $\left.\mathrm{EC}_{50}\right]$ values [mg/liter] noted parenthetically). For each of the two application timing regimens, which were conducted as separate experiments with three runs of each, AUDPC values within a column (isolate) not followed by a common letter are significantly different $(P=0.01)$; n.d. $=$ not determined. tively impacted radial growth and the production of sclerotia but not pathogenicity. We also saw no clear link between colony robustness in vitro and growth in vivo. For example, infections of untreated berries developed most slowly with resistant isolate w011 (Figs. 2 and 3) yet the rate of mycelial growth in vitro was indistinguishable from the baseline mean. In contrast, mycelial growth in vitro was significantly reduced for resistant isolate 13-54 relative to sensitive isolates (Table 2) but infections of untreated berries developed at least as fast for this isolate as for the sensitive isolate w001 (Figs. 2 and 3). These results call into question the degree to which in vitro fitness cost has relevance in the study of fenhexamid resistance, and the potential practical fitness penalty associated with fenhexamid resistance has yet to be resolved conclusively.

Fenhexamid-resistant isolates have been defined in previous studies $(2,7,16,19)$ as those with an $\mathrm{EC}_{50}$ value exceeding 0.1 or $0.13 \mathrm{mg} /$ liter. Others (15) have set the threshold value as high as 50 $\mathrm{mg} / \mathrm{liter}$. In our experiments assessing preventive activity of the fungicide, concentrations corresponding to 25 to $100 \%$ of the recommended field rate were as effective against isolate 13-54 $\left(\mathrm{EC}_{50}\right.$ $=0.148 \mathrm{mg} / \mathrm{liter}$ ) as they were against a representative baseline isolate $\left(\mathrm{EC}_{50}=0.033 \mathrm{mg} / \mathrm{liter}\right)$. In contrast, even at the highest concentration of fenhexamid, there was no discernible fungicidal effect on isolate w011 ( $\left.\mathrm{EC}_{50}=0.318 \mathrm{mg} / \mathrm{liter}\right)$. Similarly, when applied curatively $1 \mathrm{dpi}$, the various fenhexamid concentrations inhibited colonization by isolate 13-54 in a manner comparable with their inhibition of the baseline isolate but had no effect on isolate w011. Collectively, the results of the inoculation tests suggest that the threshold $\mathrm{EC}_{50}$ value most likely to be associated with resistance in the vineyard (i.e., poor control when treated with recommended rates under typical use patterns) lies between 0.15 and $0.32 \mathrm{mg} /$ liter. Although biologically based, this threshold is nevertheless an approximation based on our in vitro and detached berry assays, and the degree of its applicability to field conditions is yet to be determined. In this regard, it is interesting to note that we were unable to demonstrate selection of isolates exhibiting such in vitro sensitivity levels even with low use rates of the fungicide in our vineyard trials, although low disease pressure in 1 of the 2 years may have been a contributing factor.

The development of $B$. cinerea within berries treated curatively with fenhexamid was quantified using a duplex qPCR technique. Over time, the PC values, which can facilitate comparison among samples obtained under different conditions $(21,26)$, increased dramatically for the control berries but not for those treated with fenhexamid. In fact, there was a slight decline of the PC for the fenhexamid-treated berries when assessed at 10 and 14 dpi relative to $3 \mathrm{dpi}$, indicating a reduction in $B$. cinerea DNA during that period. Although we could not identify the cause of this reduction, it seems likely that nascent $B$. cinerea colonies were arrested or killed by the fenhexamid treatment, and then portions of their DNA degraded thereafter. These results unequivocally demonstrate the cessation of pathogen growth soon after post-inoculation treatment, and conclusively establish the curative activity of fenhexamid, a fungicide that traditionally has been marketed as a protectant. Although the scope of this portion of the study was limited and restricted to a single sensitive isolate and recommended fungicide dose, its objective was simply to demonstrate that qPCR technology can be used to monitor the progress of the pathogen (or lack thereof) within infected tissue following a curative fungicide application. Such a use of this technology has not been demonstrated previously insofar as we are aware, and our positive results suggest the possibility of expanding such experiments to examine a wider range of fungicide-pathogen interactions, thereby providing additional information on pathogen development not obtainable through standard bioassay techniques.

B. cinerea field isolates resistant to fenhexamid have been documented previously in the United States. For example, Ma and Michailides (16) reported that 11 of 234 isolates collected from various host plants in California were resistant to fenhexamid, with $\mathrm{EC}_{50}$ values of 0.13 to $3.73 \mathrm{mg} / \mathrm{liter}$. Grabke et al. (10) reported 
that 36 of $214 \mathrm{~B}$. cinerea isolates collected from commercial strawberry fields in North and South Carolina were resistant, as indicated by a fully grown germ tube on malt extract agar containing fenhexamid at $50 \mathrm{mg} / \mathrm{liter}$. Recently, on greenhouse-grown $\mathrm{Heu}$ defined $\mathrm{HydR}^{+}$strains as isolates with $\mathrm{EC}_{50}$ values for mycelial growth exceeding $2.0 \mathrm{mg} / \mathrm{liter}$ and $\mathrm{HydR}^{-}$strains as isolates with $\mathrm{EC}_{50}$ values below this threshold (8). Genetic analyses revealed chera plants, Moorman et al. (18) found a highly resistant isolate with an $\mathrm{EC}_{50}$ value for mycelial growth of approximately 2,000 $\mathrm{mg} / \mathrm{liter}$. Genetic and phenotypic analyses showed this isolate to belong to the HydR3 group (18), based on a previous system that that $\mathrm{HydR}^{+}$strains have a point mutation at codon 412 or 496 in the erg27 gene, whereas HydR $3^{-}$strains have point mutations at codon $195,309,314,336,369$, or 400 on the same gene $(1,8,27)$.

\section{Curative-1}

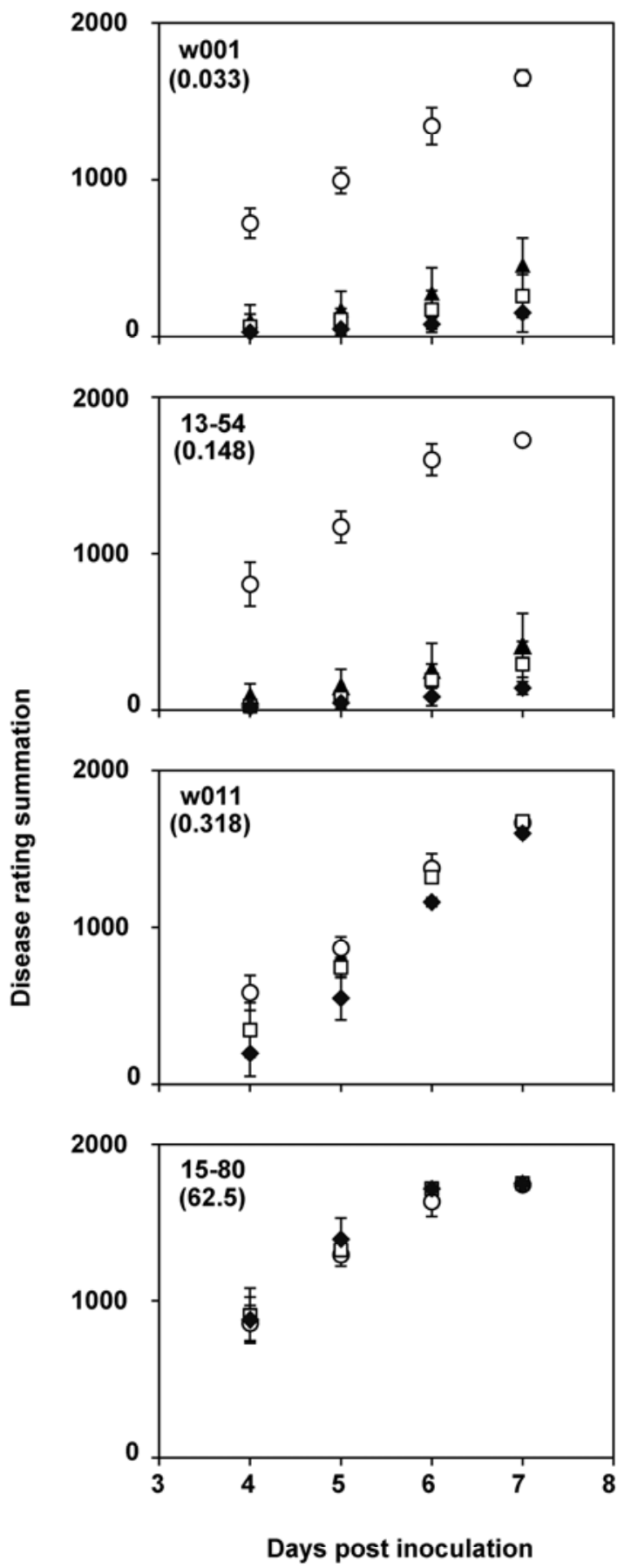

\section{Curative-3}
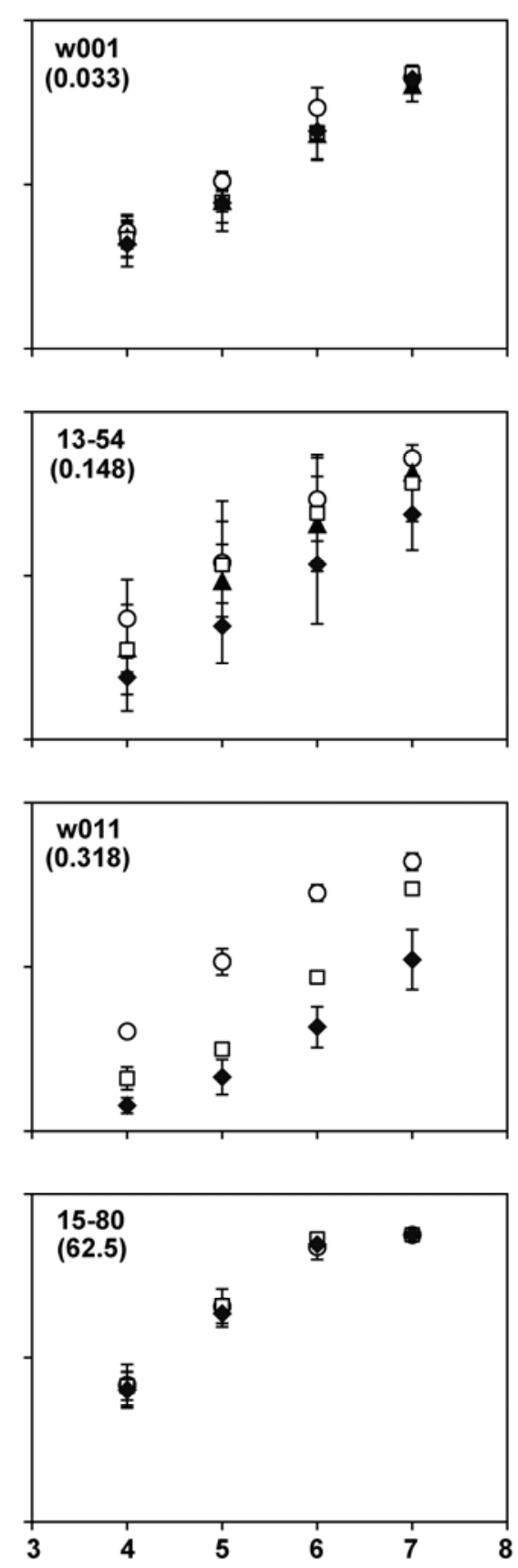

Days post inoculation

\section{O control $\quad \Delta 0.15 \mathrm{~g} / \mathrm{L} \quad \square 0.3 \mathrm{~g} / \mathrm{L} \quad 0.6 \mathrm{~g} / \mathrm{L}$}

Fig. 3. Progression of symptom development on grape berries treated curatively with different rates of fenhexamid either 1 or 3 days after inoculation with one of four Botrytis cinerea isolates exhibiting different levels of sensitivity to the fungicide (50\% effective concentration [ $\left[\mathrm{CC}_{50}\right]$ value in parentheses). Both the 1 - and 3 - day curative assays were conducted three times, with 20 berries per treatment in each run of the experiment. Disease development on each berry was rated daily from 4 through 7 days post inoculation using a scoring key ( 0 to 5 ); these values were then transformed into midpoints and summed for each treatment to provide the $y$-axis values (see Materials and Methods). Error bars represent the standard errors of the means for the three runs of each experiment, which were treated as replicates. The lowest fenhexamid concentration ( $0.15 \mathrm{~g} / \mathrm{liter})$ was not tested against isolates w011 and $15-80$. 


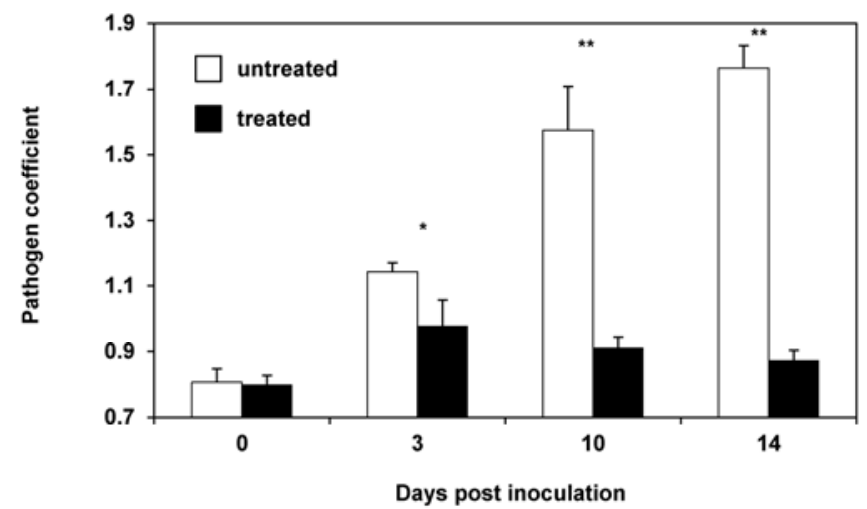

Fig. 4. Duplex quantitative polymerase chain reaction (qPCR) to detect Botrytis cinerea in grape berries following curative treatment with fenhexamid. Berries were wound inoculated with conidia of $B$. cinerea and sprayed $24 \mathrm{~h}$ later with a solution containing fenhexamid at $0.6 \mathrm{~g} /$ liter (or water for the untreated control). Total DNA was extracted from each of three berries per treatment at the time of inoculation and 3,10, and 14 days later. The DNA was subjected to a duplex qPCR assay and a pathogen coefficient was calculated to determine the relative amounts of pathogen/host DNA. Error bars represents standard deviations of three replicates berries for each treatment. Asterisks indicate a significant difference between means at the given sample time according to Student's $t$ test; ${ }^{*}$ and ${ }^{* *}$ indicate $P<$ 0.05 and 0.01 , respectively.

In our study, the $\mathrm{EC}_{50}$ value for mycelial growth of isolate 15-80 was $>60 \mathrm{mg} / \mathrm{liter}$. This isolate has a single point mutation at codon 427 in the erg27 gene and, therefore, it cannot be classified as either $\mathrm{HydR}^{+}$or HydR3 ${ }^{-}$according to current definitions. To the best of our knowledge, this is the first report of a $B$. cinerea phenotype from North American vineyards with a level of resistance to fenhexamid as high as $\mathrm{HydR}^{+}$strains. Although isolate 15-80 grew significantly more slowly than the baseline group on PDA, it infected untreated berries as rapidly as the sensitive isolate w001, and was unaffected by treatment with fenhexamid at any dose.

Although B. cinerea isolates resistant to fenhexamid have been reported frequently in numerous cropping systems throughout the world, we are unaware of any confirmed reports of control failures associated with either displacement shifts, as might be expected for highly resistant phenotypes such as our isolate 15-80, or disruptive shifts, as might be expected for moderately resistant phenotypes such as our isolate w011 (11). The underlying reasons are unclear, because both types of resistant phenotypes aggressively colonized inoculated grape berries in the presence of the fungicide in our inoculation tests. A reduction in fitness of resistant isolates has been suggested as possibly contributing to their lack of proliferation (27) and, though our in vitro results provided a modest support for this hypothesis, its limitations are discussed above. Future work focusing on this topic and monitoring of population sensitivities in response to variable fenhexamid use regimes would appear to be warranted in order to better understand the phenomenon of resistance to this fungicide at a practical level.

\section{Acknowledgments}

We thank D. Riegel for technical assistance with fungicide applications and disease ratings in the field trials.

\section{Literature Cited}

1. Albertini, C., and Leroux, P. 2004. A Botrytis cinerea putative 3-keto reductase gene (ERG27) that is homologous to the mammalian $17 \beta$-hydroxysteroid dehydrogenase type 7 gene (17 $\beta$-HSD7). Eur. J. Plant Pathol. 110:723733 .

2. Baroffio, C. A., Siegried, W., and Hilber, U. W. 2003. Long-term monitoring for resistance of Botryotinia fuckeliana to anilinopyrimidine, phenylpyrrole, and hydroxyanilide fungicides in Switzerland. Plant Dis. 87:662-666.

3. Billard, A., Fillinger, S., Leroux, P., Lachaise, H., Beffa, R., and Debieu, D. 2011. Strong resistance to fenhexamid entails a fitness cost in Botrytis cinerea, as shown by comparisons of isogenic strains. Pest Manage. Sci. Online publication. doi:10.1002/ps.2312

4. Debieu, D., Bach, J., Hugon, M., Malosse, C., and Leroux, P. 2001. The hydroxyanilide fenhexamid, a new sterol biosynthesis inhibitor fungicide efficient against the plant pathogenic fungus Botryotinia fukeliana (Botrytis cinerea). Pest Manage. Sci. 57:1060-1067.

5. De Guido, M. A., De Miccolis, A. R. M., Pollastro, S., Santomauro, A., and Faretra, F. 2007. Selection and genetic analysis of laboratory mutants of Botryotinia fuckeliana resistant to fenhexamid. J. Plant Pathol. 89:203-210.

6. Elmer, P. A. G., and Michailides, T. J. 2007. Epidemiology of Botrytis cinerea in orchard and vine crops. Pages 243-272 in: Botrytis: Biology, Pathology and Control. Y. Elad, B. Williamson, P. Tudzynski, and N. Delen, eds. Kluwer Academic Publishers, Dordrecht/Boston/London.

7. Esterio, M., Auger, J., Ramos, C., and García, H. 2007. First report of fenhexamid resistant isolates of Botrytis cinerea on grapevine in Chile. Plant Dis. 91:768

8. Fillinger, S., Leroux, P., Auclair, C., Barreau, C., Hajj, C. A., and Debieu, D. 2008. Genetic analysis of fenhexamid-resistant field isolates of the phytopathogenic fungus Botrytis cinerea. Antimicrob. Agents Ch. 52:39333940.

9. Garrett, K. A., Madden, L. V., Hughes, G., and Pfender, W. F. 2004, New applications of statistical tools in plant pathology. Phytopathology 94:9991003.

10. Grabke, A., Fernández-Ortuño, and Schunabel, G. 2013. Fenhexamid resistance in Botrytis cinerea from strawberry fields in the Carolinas is associated with four target gene mutations. Plant Dis. 97:271-276.

11. Köller, W., and Scheinpflug, H. 1987. Fungal resistance to sterol biosynthesis inhibitors: a new challenge. Plant Dis. 71:1066-1074.

12. Köller W., Wilcox, W. F., Barnard, J., Jones, A. L., and Braun, P. G. 1997. Detection and quantification of resistance of Venturia inaequalis populations to sterol demethylation inhibitors. Phytopathology 87:184-190.

13. Kretschmer, M., and Hahn, M. 2008. Fungicide resistance and genetic diversity of Botrytis cinerea isolates from a vineyard in Germany. J. Plant Dis. Prot. 115:214-219.

14. Leroux, P., Chapeland, F., Desbrosses, D., and Gredt, M. 1999. Patterns of cross-resistance to fungicides in Botryotinia fuckeliana (Botrytis cinerea) isolates from French vineyards. Crop Prot. 18:687-697.

15. Leroux, P., Fritz, R., Debieu, D., Albertini, C., Lanen, C., Bach, J., Gredt, M., and Chapeland, F. 2002. Mechanisms of resistance to fungicides in field strains of Botrytis cinerea. Pest Manage. Sci. 58:876-888.

16. Ma, Z., and Michailides, T. J. 2005. Genetic structure of Botrytis cinerea populations from different host plants in California. Plant Dis. 89:10831089.

17. Madden, L.V., Hughes, G., and Bosch, F. V. D. 2008. Pages 106-109 in: The Study of Plant Disease Epidemics. American Phytopathological Society, St. Paul, MN.

18. Moorman, G. W., Walker, A.-S., and May, S. 2012. First report of fenhexamid-resistant Botrytis cinerea causing gray mold on Heuchera in a north American greenhouse. Plant Dis. 96:147.

19. Myresiotis, C. K., Karaoglanidis, G. S., and Tzavella-Klonari, K. 2007. Resistance of Botrytis cinerea isolates from vegetable crops to anilinopyrimidine, phenylpyrrole, hydroxyanilide, benzimidazole, and dicarboximide fungicides. Plant Dis. 91:407-413.

20. Rosslenbroich, H. J., and Stuebler, D. 2000. Botrytis cinerea-history of chemical control and novel fungicides for its management. Crop Prot. 19:810 .

21. Saito, S., Dunne, K. J., Evans, K. J., Barry, K., Cadle-Davidson, L., and Wilcox, F. W. 2013. Optimisation of techniques for quantification of Botrytis cinerea in grape berries and receptacles by quantitative PCR. Aust. J. Grape Wine Res. 19:68-73.

22. Saito, S., Furuya, S., Takayanagi, T., and Suzuki, S. 2010. Phenotypic analyses of fenhexamid resistant Botrytis cinerea mutants. Pages 247-260 in: Fungicides. O. Carisse, ed. InTech Publisher, Rijeka, Croatia.

23. Scherm, H., and Ojiambo, P. S. 2004, Applications of survival analysis in botanical epidemiology. Phytopathology 94:1022-1026.

24. Suarez, M. B., Walsh, K., Boonham, N., O’Neill, T., Pearson, S., and Barker, I. 2005. Development of real-time PCR(TaqMan) assays for the detection and quantification of Botrytis cinerea in planta. Plant Physiol. Biochem. 43:890-899.

25. Suty, A., Pontzen, R., and Stenzel, K. 1999. Fenhexamid-sensitivity of Botrytis cinerea: determination of baseline sensitivity and assessment of the risk of resistance. Pflanzenschutz Nachr. Bayer. (Ger. Ed.) 52:145157.

26. Valsesia, G., Gobbin, D., Patocchi, A., Vecchione, A., Pertot, I., and Gessler, C. 2005. Development of a high-throughput method for quantification of Plasmopara viticola DNA in grapevine leaves by means of quantitative real-time polymerase chain reaction. Phytopathology 95:672-678.

27. Walker, A.S., Micoud, A., Rémuson, F., Grosman, J., Gredt, M., and Leroux, P. 2013. French vineyards provide information that opens ways for effective resistance management of Botrytis cinerea (grey mould). Pest Manage. Sci. 69:667-678.

28. Weber, R. W. S. 2010. Occurrence of Hyd R3 fenhexamid resistance among Botrytis isolates in Northern German soft fruit production. J. Plant Dis. Prot. 117:177-179.

29. Weber, R. W. S., and Hahn, M. 2011. A rapid and simple method for determining fungicide resistance in Botrytis. J. Plant Dis. Prot. 118:17-25.

30. Ziogas, B. N., Markoglou, A. N., and Malandrakis, A. A. 2003. Studies on the inherent resistance risk to fenhexamid in Botrytis cinerea. Eur. J. Plant Pathol. 109:311-317. 